\title{
Orientace puklin a zlomů v kulmských horninách jižně od Skalky u Prostějova
}

\author{
Orientation of joints and faults in the Culm sediments south of Skalka near Prostějov
} Josef Havíŕ $\square$

Ústav fyziky Země, PřF MU, Tvrdého 12, 60200 Brno, Česká republika

Key words:

joints, faults, orientation of structures, Culm sediments

$\rightrightarrows$ havir@ipe.muni.cz

Editor:

Milan Geršl
Doporučená citace článku: Haviŕ, J. (2020). Orientace puklin a zlomů v kulmských horninách jižně od Skalky u Prostějova. - Geologické výzkumy na Moravě a ve Slezsku, 27 , $1-2,63-68$.

DOI: https://doi.org/10.5817/ GVMS2020-13172

\begin{abstract}
The article informs about results of orientation analysis of fractures (joints and faults) carried out in the region south of Skalka (near Prostějov). This region is situated on the E margin of the Bohemian Massif near the Kvasice Fault. Fractures were studied mostly at the sites of the Culm sediments, the set of ten steep joints were found also at one site of the Miocene clastics. In the Culm sediments, several sets of steep to subvertical fractures (mostly joints) were distinguished, at some sites also gently to moderately dipping fractures were found. Some of planes were tectonized. At the site SP09A (in the quarry north of Pivin) the relatively significant steep NNW-SSE strike-slip fault was observed, which is probably part of fault structure limiting the eastern margin of uplifted block of the Culm rocks south of Skalka.
\end{abstract}

\section{Úvod}

Studie přednostní orientace puklin a zlomů prezentovaná v tomto článku byla prováděna $\mathrm{v}$ rámci projektu České geologické služby zaměřeného na hydrogeologické problémy související s minerálními vodami v lázních ve Skalce, jižně od Prostějova. Cílem tohoto článku je stručně informovat o charakteristice puklinové sítě a o zlomech zjištěných na horninových výchozech v prostoru jižně od Skalky. Pukliny a zlomy byly sledovány převážně na dostupných výchozech kulmských hornin, v omezené míře byly ale nalezeny a proměřeny diskontinuity také na jedné lokalitě neogenních klastik.

\section{Stručný nástin geologické situace a pozice studovaných lokalit}

Studovaný prostor (obec Skalka a její jižní okolí) se nachází na východním okraji Českého masivu, ve vzdálenosti jen přibližně tří až pěti km jz. od kvasického zlomu (viz obr. 1), který je součástí tzv. poruchového pásma Hané a představuje jižní tektonické omezení Hornomoravského úvalu s významnou pliocenní až kvartérní výplní (Suk et al. 1996; Špaček et al. 2015). Poruchové pásmo Hané je širokou tektonickou zónou zahrnující ŕadu zlomů převážně tzv. sudetského směru (tj. směr SZ-JV) vyznačujících se neogenní až kvartérní reaktivací, projevující se mimo jiné porušením čela západokarpatských př́íkrovů a kvartérních sedimentů Hornomoravského úvalu (napřr. Růžička 1989; Suk et al. 1996; Špaček et al. 2015).

Na podkladu kulmských hornin myslejovického souvrství (Dvořák 1993) leží neogenní sedimenty karpatské předhlubně. Na jižním okraji Skalky a jižně od Skalky vystupují kulmské horniny z pod neogenního pokryvu, přičemž 


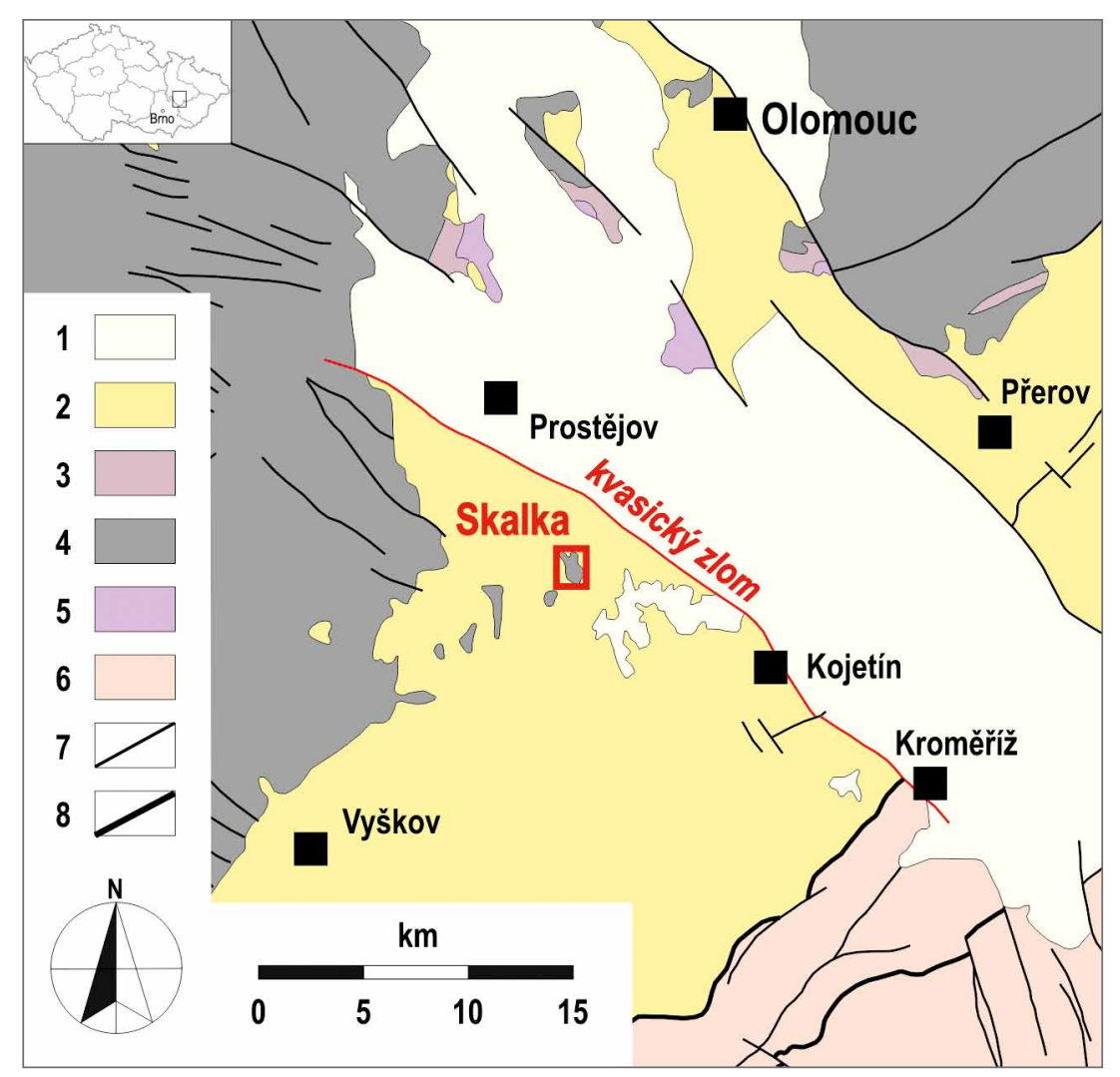

Obr. 1: Schematická geologická mapa regionu širšího okolí zkoumaného regionu (sestaveno a modifikováno podle map 1 : 200 000; Buday 1989, 1990; Roth 1990; Svoboda 1990) s vyznačeným průběhem kvasického zlomu (červená linie) a výskytem kulmu jižně od Skalky (červený obdélník). Vysvětlivky: 1 pliocén; 2 - miocén; 3 - kulm; 4- devon; 5 - krystalinikum; 6 -západokarpatské př́krovy; 7 - zlomy; 8 - čela př́íkrovů. Fig. 1: Geological scheme of study area and wider surroundings (compiled and modified after maps 1:200 000: Buday 1989, 1990; Roth 1990; Svoboda 1990) with marked Kvasice Fault (red line) and region of the Culm outcrops south of Skalka (red rectangle). Legend: 1 - Pliocene; 2 - Miocene; 3 - Culm; 4 - Devonian; 5 - crystalline units; 6 - West Carpathian nappes; 7 - faults; 8 - front of nappes.

na mapě $1: 50000$ (Rủžička 1995, viz obr. 2). Všechny výchozy studované v rámci této práce se nacházejí jižně od zmíněného zsz.-vjv. zlomu. Studium puklin a zlomů největši odkrytá plocha se nachází na mírně vyvýšeném hřbetu v prostoru „U jezírek“ (obr. 2).

Blízkost kvasického zlomu a hlubší uložení kulmských hornin s. od Skalky, kde byl jejich povrch navrtán až v hloubce téměř 300 metrů (Zapletal 2004), jsou fakta podporující předpoklad existence zsz.-vjv. orientovaného zlomu také v prostoru obce Skalka, tak, jak je znázorněn

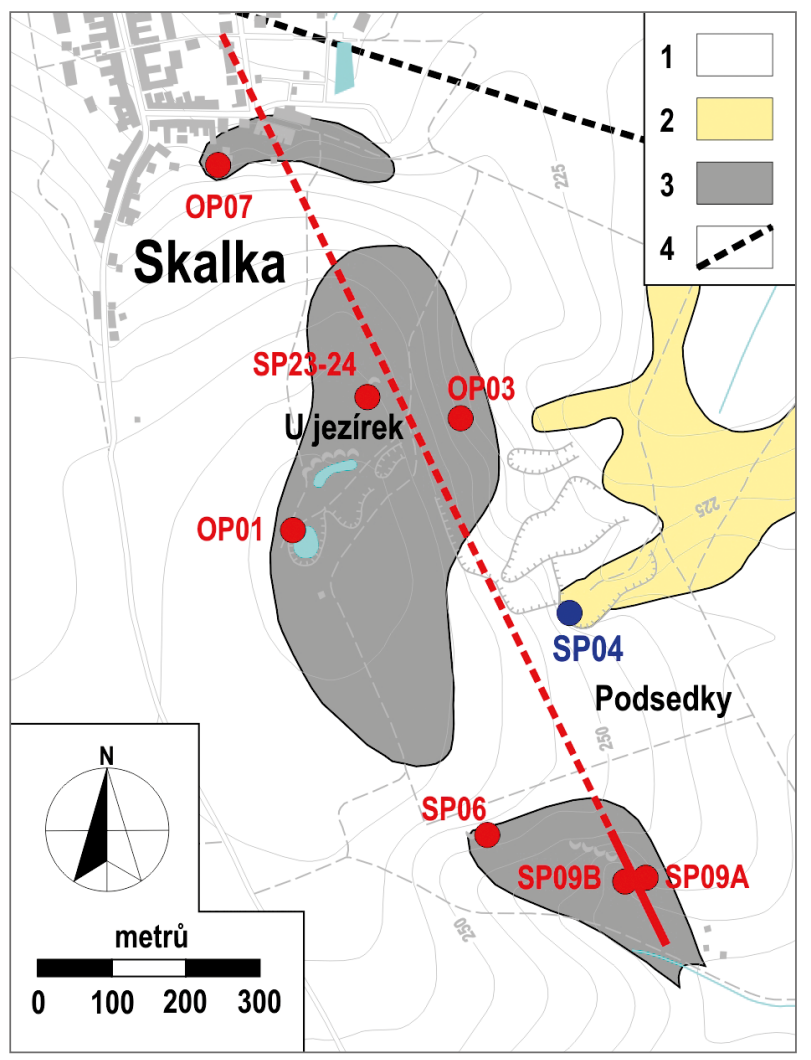

kulmských hornin bylo provedeno na celkem sedmi lokalitách situovaných na jižním okraji Skalky (lokalita OP07) a jižně od Skalky (viz obr. 2). Dále byly zjištěny diskontinuity (pukliny, možná drobné zlomy) v neogenních sedimentech odkrytých v pískovně jjv. od Skalky (lokalita SP04).

\section{Přednostní orientace puklin a zlomů}

Na lokalitách na jižním okraji obce Skalka a jižně od obce Skalka byla změřena orientace celkem 511 ploch puklin a zlomů (501 v kulmských horninách a $10 \mathrm{v}$ neogenních sedimentech), z nichž 68 bylo reprezentováno zlomy se striacemi (obr. 3).

Mezi měřenými puklinami a zlomy převládaly strmé až subvertikální plochy. Na všech lokalitách kulmských hornin bylo možné na základě geometrické analýzy rozlišit více než jeden systém strmých ploch, přičemž dva systémy obvykle patřily $\mathrm{k}$ dominantním. K systémům

Obr. 2: Schematická geologická mapa regionu jižně od Skalky (podle Růžičky 1995) s vyznačenými lokalitami (červená kolečka - lokality v horninách kulmu; modré kolečko - lokalita v miocenních sedimentech). Plnou červenou linií je vyznačen zlom pozorovaný na lokalitě SP09A, přerušovaná červená čára je pak ideovým znázorněním protažení tohoto zlomu ve zjištěném směru $\mathrm{k} S S Z$. Vysvětlivky: 1 - kvartér; 2 - miocén; 3 - kulm; 4 - zlomy.

Fig. 2: Geological scheme of the region south of Skalka (after Růžička 1995) with marked studied sites (red circles - outcrops of the Culm sediments; blue circle - outcrop of the Miocene clastics). The solid red line shows the fault observed at the site SP09A, the dashed red line illustrates in a simplified way the idea of prolongation of this fault to NNW. Legend: 1 - Pliocene; 2 - Miocene; 3 - Culm; 4 - faults. 


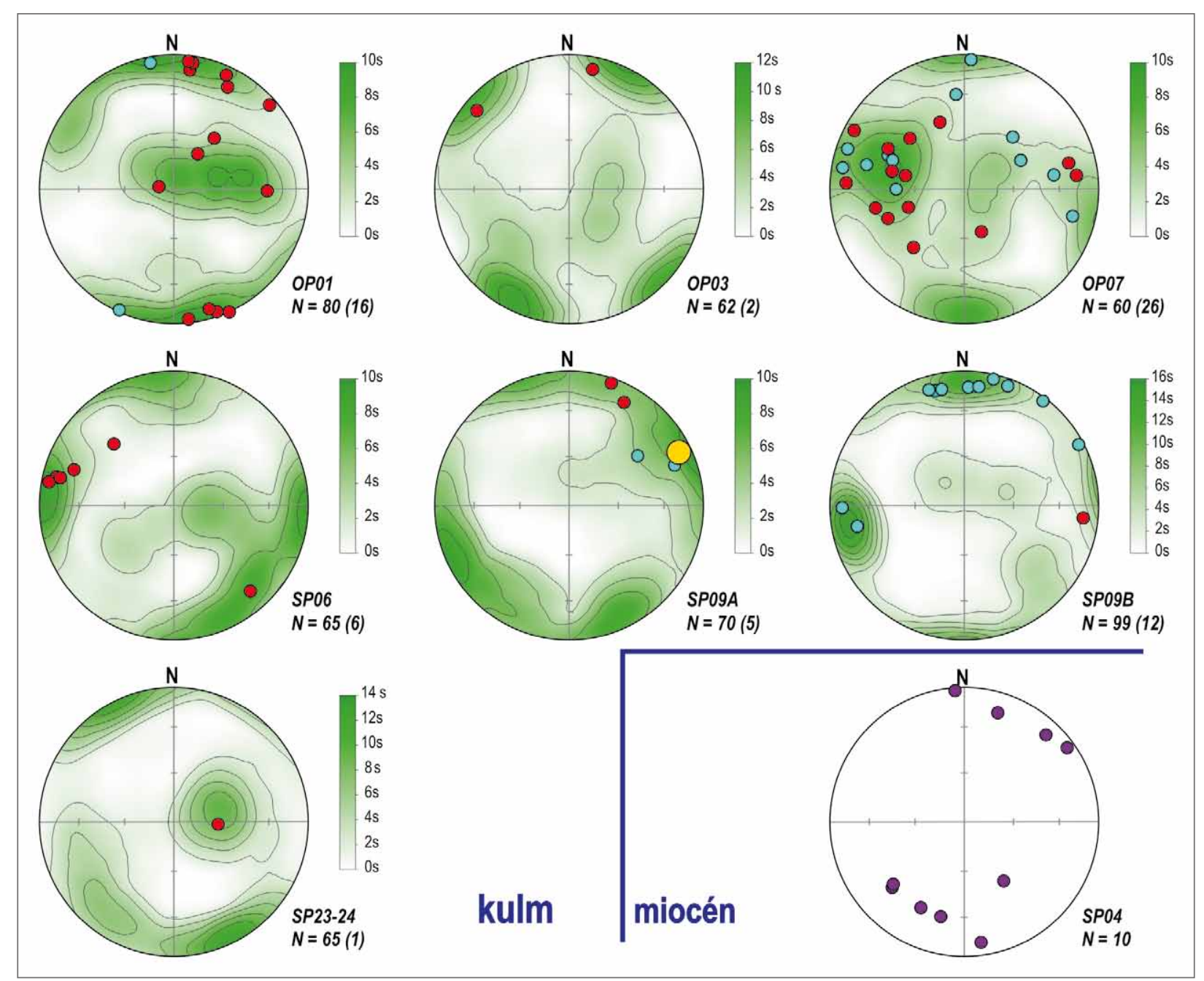

Obr. 3: Diagramy pólů ploch diskontinuit (puklin a zlomů) měřených na lokalitách na jižním okraji Skalky a jižně od Skalky (Lambertova projekce, spodní polokoule). Konturové diagramy znázorňují orientace pólů všech ploch měřených v kulmských horninách. Pro výpočet hustot v konturových diagramech byly použity rovnice převzaté z Vollmerova algoritmu (Vollmer 1995). Body znázorňují póly zlomů se striacemi měřených v kulmských horninách (modrá kolečka - malé plochy, červená kolečka - velké plochy, žluté kolečko - plocha významného zlomu zjištěného na lokalitě SP09A, čísla v závorkách jsou počty zlomů se striacemi) a póly puklin měřených na lokalitě miocenních klastik (fialová kolečka).

Fig. 3: Diagrams of fracture poles measured at sites on the southern edge of Skalka and south of Skalka (Lambert projection, lower hemisphere). Contoured diagrams show orientations of poles of all fractures measured in the Culm rocks. Vollmer equations (Vollmer 1995) were used for calculation of density for contoured diagrams. Points show poles of faults with striations measured in the Culm rocks (blue circles - small planes, red circles - great planes, yellow circle - significant fault found at the site SP09A, numbers in brackets are numbers of fault striae data) and poles of joints measured at the site of the Miocene clastics (violet circles).

projevujícím se výrazně na více lokalitách patří strmé diskontinuity orientované přednostně ve směru $\mathrm{V}-\mathrm{Z}$ (lokality OP01, P07, SP06 a SP09B), S-J (lokality OP07, SP06 a SP09B), SV-JZ až VSV-ZJZ (lokality OP01, OP03, SP09A a SP23-24) a SZ-JV až SSZ-JJV (lokality OP03, SP09A a SP23-24). Mezi zjištěnými zlomy se striacemi převládaly zejména plochy systémů směru $\mathrm{V}-\mathrm{Z}$ a $\mathrm{S}-\mathrm{J}$, plochy jiných systému byly tektonizovány (tj. aktivovány či reaktivovány jako zlomy za vzniku striací) v menší míře.

Na většině lokalit kulmských hornin pak byly pozorovány také plochy mírně až stř̌edně ukloněné. $V$ případě středně ukloněných ploch převládaly systémy se středním směrem sklonu spádnice převážně k západu (lokality OP1, OP3, SP06, SP23-24). Naopak výjimečně výrazný systém diskontinuit ukloněných pod středními úhly $\mathrm{k} \mathrm{V}$ až VJV, často tektonizovaných (se striacemi) byl pozorován na lokalitě OP07 (při j. okraji obce Skalka).

Striace nalezené na plochách zlomů většinou umožňovaly určit pouze směr pohybu, nikoli jeho smysl. Pokud byly na ploše přítomny kinematické indikátory dokládající také smysl pohybu, šlo ve všech případech o střechovitě se překládající růstová vlákna minerálů (tj. o struktury typu „crystal fibers“ ve smyslu Hancocka 1985; Doblase 1998 a dalších). Soubor kinematických dat byl ovšem značně heterogenní. K pohybům na plochách zlomů zjevně docházelo během více tektonických procesů, které byly spojeny s působením různě orientovaných napětových polí. Lze předpokládat, že řada zlomů byla reaktivována opakovaně.

Konkrétní napětové pole, spojené s alespoň některými zjištěnými pohyby na zlomech, bylo možné určit 


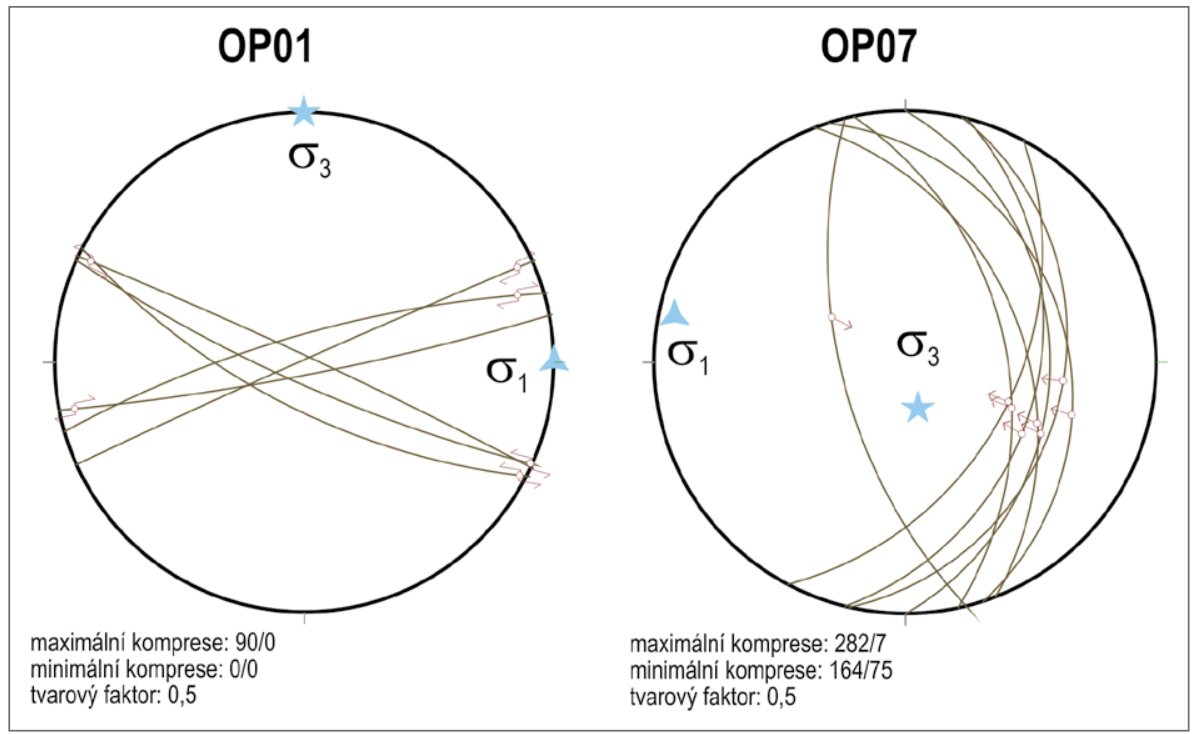

Obr. 4: Orientace hlavních os napětí odvozených programem MIM5 (Yamaji et al. 2005) pro zlomy se striacemi (velké oblouky) zjištěné na lokalitách OP01 (vlevo) a OP07 (vpravo).

Fig. 4: Orientations of principal stress axes determined by program MIM5 (Yamaji et al. 2005) for fault-striae data (great arcs) measured at the sites OP01 (left) and OP07 (right).

pouze na dvou lokalitách (OP01 a OP07). Pro výpočet byl použit program MIM5 (Yamaji et al. 2005) využívající metody vícenásobné inverze (Otsubo et al. 2006; Yamaji 2000). Na obou lokalitách byl zjištěn vliv napětového pole spojeného se subhorizontální kompresí ve směru $\mathrm{V}-\mathrm{Z}$ až VJV-ZSZ (obr. 4).

Na lokalitě OP01 byla osa minimální komprese (respektive maximální extenze) rovněž subhorizontální a působila ve směru S-J. Toto pole pak bylo spojené se subhorizontálními posuny na strmých až subvertikálních zlomech.

$\mathrm{V}$ př́padě lokality OP07 byla osa minimální komprese naopak subvertikální. Zjištěné napětové pole bylo spojeno s přesmykovými pohyby na drobných zlomech ukloněných pod středními úhly převážně k východu. Tyto zlomy byly součástí k východu ukloněné násunové zóny, která tvoří nejvýznamnější tektonický prvek pozorovaný na lokalitě OP07. Na jiných lokalitách podobná zóna nalezena nebyla, ani nebyly na jiných lokalitách pozorovány významnější systémy diskontinuit s podobnou orientací. Je proto otázkou, zda diskutovaná násunová zóna představuje tektonický prvek pouze lokálního významu, nebo zda se podobné ( $\mathrm{k}$ východu ukloněné) násuny vyskytují i na jiných místech kulmských výchozů u Skalky, třebaže nebyly na jiných lokalitách v rámci tohoto výzkumu doloženy.

Stáří zjištěných paleonapětových polí nelze blíže určit. Jejich působení mohlo být spojeno jak s variskými tak i s povariskými tektonickými procesy.

V neogenních sedimentech byly zjištěny diskontinuity vzniklé křehkou deformací na lokalitě SP04 (obr. 3). Šlo o převážně strmé plochy orientované ve směru V-Z až SZ-JV. Jejich orientace dobře koresponduje s orientacemi zlomů se striacemi zjištěnými v lomu s. od Pivína (lokality SP09A a SP09B). Lze tedy předpokládat, že jejich geneze mohla souviset s reaktivací drobných zlomů v podložním kulmu.

\section{Výrazný zlom směru SSZ-JJV}

Zcela zásadní strukturní prvek byl pozorován ve v. části lomu v jižní části studovaného prostoru, severně od Pivína (lokalita SP09). Šlo o významnou zlomovou strukturu s řádově několik decimetrů širokým jádrem tvořeným drcenou zónou, zřetelně procházející celým lomem. Orientace této zlomové struktury byla přímo měřena na lokalitě SP09A (viz obr. 5, směr sklonu a sklon plochy je 244/80). $\mathrm{Na}$ ploše bylo pozorováno také rýhování dokládající převažující horizontální složku pohybu, smysl pohybu (pravostrannost či levostrannost) nebylo bohužel možné dostatečně věrohodně doložit. Na význam zlomové struktury ukazuje také fakt, že přednostní orientace hlavních systémů diskontinuit (puklin či zlomů) měřených v opuštěném lomu s. od Pivína se východně od zlomu (lokalita SP09A) a západně od zlomu (lokalita SP09B) vzájemně liší, přestože vzdálenost mezi oběma místy měření je pouze cca 20 metrů. Přitom charakter přednostní orientace diskontinuit pozorovaný západně od zlomu (lokalita SP09B) velmi dobře odpovídá přednostní orientaci ploch měřených na lokalitě SP06 situované cca 200 metrů dále k západu od diskutovaného lomu. Zjištěný zlom tedy zjevně představuje významnější tektonické rozhraní.

Severo-severozápadní pokračování diskutovaného zlomu zřetelně koresponduje s topograficky významným svahem situovaným mezi kulmskými výchozy v místě „U jezírek“ (lokalita OP01) a pískovnou s neogenními klastiky (lokalita SP04) nacházející se východně od kulmských výchozů. Jak plyne z topografického podkladu mapy na obrázku 2, dno pískovny s neogenními sedimenty se nachází o více než 40 metrů níže oproti výchozům kulmu v místě „U jezírek“, přičemž elevace tvořená kulmskými horninami je oproti východně (a níže) ležícímu prostoru s neogenním pokryvem ohraničena výše zmíněným relativně příkrým svahem orientovaným ve směru SSZ-JJV. Směr svahu velmi dobře odpovídá směru výrazné zlomové struktury zjištěné v opuštěném lomu s. od Pivína (lokalita SP09). Tato fakta ukazují, že východní omezení kulmských hornin vystupujících na povrch jižně od Skalky je přinejmenším částečně tektonické, tvořené strmým zlomovým systémem směru SZ-JV až SSZ-JJV oddělujícím západní kru (relativně vystouplou) od východní (relativně zakleslé). V lomu na lokalitě SP09 je pak pravděpodobně odkryt zlom, který je součástí diskutovaného zlomového systému. 


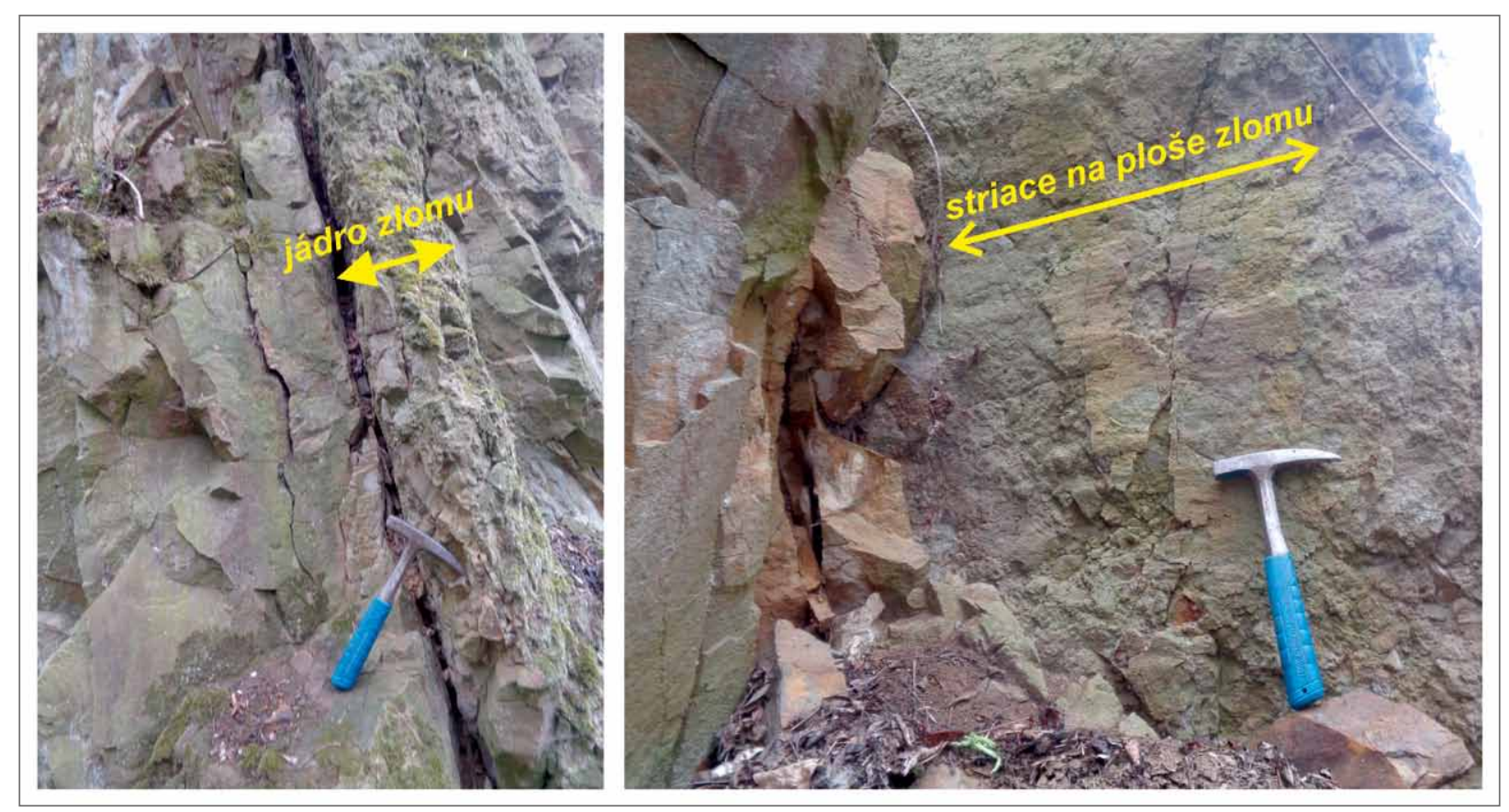

Obr. 5: Významná zlomová struktura směru SSZ-JJV s převážně horizontálním charakterem pohybu pozorovaná v lomu severně od Pivína (lokalita SP09A).

Fig. 5: Significant NNW-SSE fault with mostly strike-slip kinematics studied in the quarry situated north of Pivín (site SP09A).

\section{Závěr}

Na základě studia puklin a zlomů provedeného na lokalitách kulmských hornin na jižním okraji obce Skalka a jižně od obce Skalka lze konstatovat následující závěry:

1. Relativně vystouplá kra, vyznačující se povrchovými výchozy kulmských hornin, je na svém východním okraji tektonicky ohraničena strmým zlomem směru SSZJJV. Strmá struktura, která je s vysokou pravděpodobností součástí daného zlomu, je odkryta v opuštěném lomu $\mathrm{v}$ jižní části studovaného prostoru, severně od Pivína, kde odděluje dva bloky kulmských hornin. Na základě topografie a nadmořské výšky povrchových výchozů kulmských sedimentů (západně od zlomu) a neogenních sedimentů (východně od zlomu) lze očekávat pokračování diskutovaného tektonického rozhraní dále $\mathrm{k}$ SSZ až do prostoru obce Skalka, a to konkrétně do prostoru místních lázeňských pramenů.

2. Horninové prostředí kulmských sedimentů $\mathrm{v}$ relativně vystouplé kře jižně od Skalky je v celém svém rozsahu porušeno několika systémy strmých velkých diskontinuit (převážně puklin, v menší míře zlomů). Na každém místě lze pozorovat alespoň dva různě orientované systémy těchto diskontinuit. Tyto diskontinuity mohou být přívodními cestami pro fluida migrující skrze horninové prostředí tvořené sedimenty kulmu, přičemž hypotetická migrace fluid skrze puklinovou sít je možná v různých směrech (jak ve v.-z. tak v i s.-j.). Předložené studium ovšem nemůže odpovědět na otázku, jak velké množství fluid by bylo schopno diskutovanou puklinovou sítí proudit.

3. Z tektonického schématu širšího okolí obce Skalka lze pak ještě také předpokládat tektonické omezení relativně vyzdvižené kry také na jejím severním okraji, přičemž toto rozhraní by bylo tvořeno strmým zlomem směru ZSZ-VJV. Př́ímo v terénu ale nebyly v rámci předkládané studie žádné tektonické prvky, které by mohly daný zlom blíže charakterizovat, pozorovány, protože sledované odkryvy se většinou nacházejí ve větší vzdálenosti (jižně) od předpokládaného průběhu zlomu.

\section{Poděkování}

Příspèvek vznikl s finanční podporou projektu ČGS číslo 388200. Děkuji recenzentưm, Radomíru Grygarovi a Jiřímu Rezovi, za cenné pripomínky. 


\section{Literatura}

Buday, T. (ed.) (1989). Geologická mapa ČSSR. Mapa předčtvrtohorních útavrů 1 : 200 000, list Brno. - Ústřední Ústav Geologický Praha.

Buday, T. (ed.) (1990). Geologická mapa ČSSR. Mapa předčtvrtohorních útavrů $1: 200$ 000, list Gottwaldov. - Ústř̌ední Ústav Geologický Praha.

Doblas, M. (1998). Slickenside kinematic indicators. - Tectonophysics, 295, 187-197.

Dvořák, J. (1993). Moravské paleozoikum. - In: Přichystal, A., Obstová, V., Suk, M. (eds): Geologie Moravy a Slezska, 41-58.

Hancock, P. L. (1985). Brittle microtectonics: principles and practice. - Journal of Structural Geology, 7, 3/4, 437-457.

Otsubo, M., Sato, K., Yamaji, A. (2006). Computerized identification of stress tensors determined from heterogeneous fault-slip data by combining the multiple inverse method and k-means clustering. - Journal of Structural Geology, 28, 991-997. https://doi.org/10.1016/j.jsg.2006.03.008

Roth, Z. (ed.) (1990). Geologická mapa ČSSR. Mapa předčtvrtohorních útavrů 1 : 200 000, list Olomouc. - Ústřední Ústav Geologický Praha.

Růžička, M. (1989). Pliocén Hornomoravského úvalu a Mohelnické brázdy. - Sborník geologických věd, Antropozoikum, 19, $129-151$.

Růžička, M. (ed.) (1995). Geologická mapa ČR, list 24-24 Prostějov. - ČGÚ Praha.

Suk, M., Reichwalder, P., Šefara, J., Schenk, V. (1996). Regionalizace v geologických vědách. - Folia Facultatis Scientiarum Naturalium Universitatis Masarykianae Brunensis, Geologia 38, 1-227.

Svoboda, J. (ed.) (1990). Geologická mapa ČSSR. Mapa předčtvrtohorních útavrů $1: 200$ 000, list Česká Třebová. - Ústřední Ústav Geologický Praha.

Špaček, P., Bábek, O., Štěpančíková, P., Švancara, J., Pazdírková, J., Sedláček, J. (2015). The NysaMorava Zone: an active tectonic domain with Late Cenozoic sedimentary grabens in the Western Carpathians' foreland (NE Bohemian Massif). - International Journal of Earth Sciences (Geol Rundsch), 104, 963-990. https://doi.org/10.1007/s00531-014-1121-7

Vollmer, F. W. (1995), C program for automatic contouring of spherical orientation data using a modified Kamb method, Computers \& Geoscience, 21, 1, 31-49. https://doi.org/10.1016/0098-3004(94)00058-3

Yamaji, A.,Sato, K., Otsubo, M. (2005): Multiple inverse method software package. User's guide. - MS Divison of Earth and Planetary Sciences, Kyoto University.

Yamaji, A. (2000). The multiple inverse method: a new technique to separate stress from heterogeneous fault-slip data. - Journal of Structural Geology, 22, 441-452. https://doi.org/10.1016/S0191-8141(99)00163-7

Zapletal, J. (1985). Př́spěvek k paleogeografickému vývoji sedimentace spodního badenu na střední Moravě. - Scripta Fac. Sci. Nat. Univ. masaryk. Brunensis, 31-32, Geology, 87-98. 